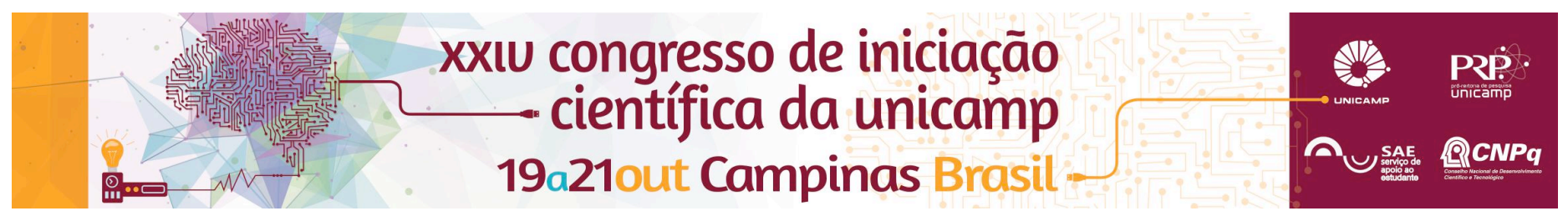

\title{
AS CANÇÕES DE CÂMARA DE CARLOS ALBERTO PINTO FONSECA SOBRE POEMAS CHINESES TRADUZIDOS POR PAULO MENDES CAMPOS: EDITORAÇÃO E ANÁLISE MUSICAL
}

\section{Letícia Fais*}

\section{Resumo}

Neste trabalho, foram exploradas as canções de câmara de Carlos Alberto Pinto Fonseca (CAPF) sobre poemas chineses traduzidos por Paulo Mendes Campos. Os manuscritos foram editados com o programa Sibelius 7.5. Foram sugeridos dedilhados para a parte do piano e foi feita a transcrição fonética dos textos das canções. Por fim, os processos composicionais de CAPF foram investigados quanto a semelhanças com técnicas exploradas na Música Erudita Ocidental durante o século XX. Foram encontrados traços minimalistas e impressionistas nessas peças, além de características atonais e relações entre o texto e a música que fortalecem a mensagem transmitida.

\section{Palavras-chave:}

Carlos Alberto Pinto Fonseca, Paulo Mendes Campos, canção de câmara brasileira

\section{Introdução}

Carlos Alberto Pinto Fonseca viveu de 07.06.1933 a 27.05.2006. Foi regente, pianista, professor e compositor. Ele se descrevia como um compositor eclético, mais do que nacionalista. Escreveu canções inspiradas na cultura afro-brasileira, além de se basear em textos de escritores brasileiros e poemas chineses traduzidos por Paulo Mendes Campos. O objetivo deste trabalho é recuperar essas canções que se encontram manuscritas, editandoas. Também se busca oferecer dedilhados e transcrições fonéticas para auxílio de intérpretes, além de analisar técnicas composicionais empregadas.

\section{Resultados e Discussão}

Os manuscritos foram editados, porém na canção "Fumaça" não foi possível recuperar um trecho da letra, por estar muito rasurado e com palavras sobrepostas. Notas musicais foram corrigidas pelo próprio compositor, usando letras " $x$ " nas alturas realmente desejadas. $O$ compositor já indicara um dedilhado para o início da canção "Ao Espelho" e, para o restante, foram sugeridos dedilhados. Foram feitas as transcrições fonéticas dos textos para possibilitar sua pronúncia por não-falantes do português brasileiro. Em "Ao Espelho", "Desespero em Luz" e "Fumaça" o compositor usa as doze notas da escala cromática e associa técnicas melódicas e de acordes para trazer uma sonoridade atonal. Elementos minimalistas e impressionistas também foram encontrados. Destaca-se o uso de síncopas, ostinatos e a exploração de motivos rítmicos e melódicos como elementos de unificação e estruturação das canções.

\section{Conclusões}

"Ao Espelho", "Desespero em Luz", "Meu Nome" e "Moinho" foram as canções editadas com sucesso. Este trabalho de edição foi de grande contribuição à comunidade acadêmico-musical por disponibilizar um repertório de alto nível artístico. Contribuiu ainda para a divulgação da obra de CAPF e sua execução será possível para músicos do mundo todo.

\section{$\mathrm{PIBIC/CNPq}$}

\section{Agradecimentos}

${ }^{1}$ FERNANDES, A. J. FERNANDES, Angelo José. Missa Afro-Brasileira (de Batuque e Acalanto) de Carlos Alberto Pinto Fonseca: aspectos interpretativos. 2004. Dissertação - Instituto de Artes da Universidade Estadual de Campinas. Campinas, 2004.

KOSTKA, S. Materials and Techniques of Twentieth-Century Music. $3^{\mathrm{a}}$ edição. Nova Jersey: Pearson Prentice Hall, 2006. 334 páginas. 